Instructions for authors, subscriptions and further details:

\title{
http://rimcis.hipatiapress.com
}

\section{An Analysis of Families' Experiences with Young Children with Intellectual and Developmental Disabilities (IDDs) during COVID-19 Lockdown in Pakistan}

Malik Mamoon Munir ${ }^{1}$, Ume Rubaca ${ }^{2}$, Malik Haroon Munir ${ }^{3}$, Bakhtawar Munir ${ }^{2}$

1) Bahria University Islamabad, Pakistan

2) Comsats University Islamabad, Pakistan

3) Crawford School of Public Policy, Australian National University, Australia

Date of publication: Issue published 30 March 2021

Edition period: March 2021 - July 2021

To cite this article: Munir, M.M., Rubaca, U., Munir, M.H., \& Munir, B. (2021). An Analysis of Families' Experiences with Young Children with Intellectual and Developmental Disabilities (IDDs) during COVID-19 Lockdown in Pakistan. International and Multidisciplinary Journal of Social Sciences, 10(1), 81-103. doi: 10.17583/rimcis.2021.7546

To link this article: http://doi.org/10.17583/rimcis.2021.7546

\section{PLEASE SCROLL DOWN FOR ARTICLE}

The terms and conditions of use are related to the Open Journal System and to Creative Commons Attribution License(CC-BY). 


\section{An Analysis of Families' Experiences with Young Children with Intellectual and Developmental Disabilities (IDDs) during COVID-19 Lockdown in Pakistan}

Malik Mamoon Munir

Bahria Univesity Islamabad

Malik Haroon Munir

Australian National University
Ume Rubaca

Comsats Univesity Islamabad

Bakhtawar Munir

Comsats University Islamabad

\section{Abstract}

The shadow impacts of the COVID-19 pandemic are critical, especially for children with intellectual and/or developmental disabilities (IDDs). Financial constraints and home confinement have increased the challenges for caregivers to meet the educational and health needs of children with IDDs. Hence, this research examines the impact of COVID-19 lockdown on families with IDDs children in rural Pakistan. Overall, 176 parents participated in this study and provided valuable responses through interview technique. Parents responded to five (05) open-ended questions. Results indicated that parents of children with IDDs are facing various challenges including financial constraints, social lockdown, deteriorated health conditions of their children, reduced or no health services, closure of educational institutes, negative behavioral impacts, and slow mental development. Still, a subset of parents also reported the positive side of lockdown, indicating that staying at home resulted in improved relationships. The findings of the study suggest that parents of children with IDDs are confronted with significant challenges that increase their stress.

Keywords: COVID-19, lockdown, pandemic, children, Pakistan 
Sciences Vol. 10 No. 1 March 2021 pp. 81-103

\section{Un Análisis de la Experiencia de Familias con Niños Pequeños con Discapacidades Intelectuales y del Desarrollo (IDD) durante el Confinamiento por COVID-19 en Pakistán}

Malik Mamoon Munir

Bahria University Islamabad

Malik Haroon Munir

Australian National University
Ume Rubaca

Comsats Univresity Islamabad

Bakhtawar Munir

Comsats University Islamabad

\section{Resumen}

Los impactos oscuros de la pandemia de COVID-19 son críticos, especialmente para niños y niñas con discapacidades intelectuales y/o del desarrollo (IDD). Las limitaciones financieras y el confinamiento en el hogar han aumentado los desafíos para que los cuidadores satisfagan las necesidades educativas y de salud de los niños con IDD. Esta investigación examina el impacto del confinamiento por COVID-19 en familias con niños con IDD en las zonas rurales de Pakistán. 176 padres y madres participaron en este estudio y proporcionaron respuestas valiosas en entrevistas. Los padres y madres respondieron a cinco preguntas abiertas. Los resultados indicaron que se enfrentan a varios desafíos, que incluyen restricciones financieras, bloqueo social, deterioro de las condiciones de salud de sus hijos, servicios de salud reducido o nulo, cierre de instituciones educativas, impactos negativos en el comportamiento y desarrollo mental lento. Aún así, un subconjunto de padres también informó el lado positivo del encierro, lo que indica que quedarse en casa resultó en mejores relaciones. Los hallazgos sugieren que los padres de niños con IDD se enfrentan a desafíos importantes que aumentan su estrés.

Palabras clave: COVID-19, confinamiento, pandemia, niños, Pakistán 
The COVID-19 pandemic has been deemed not only the most significant worldwide health crisis of today, but the greatest global challenge since World War II (Roesch, Amin, Gupta \& Moreno, 2020). The COVID-19 virus has affected individuals on all continents of the globe (Neece, Mclntyre \& Fenning, 2020). The medical science community has struggled to create the cure against COVID-19 and ended up with the formula of social distancing and preventive steps to avert its spread (World Health Organization, 2020). Besides posing the greatest health challenge, COVID-19 has also provided the unprecedented socio-economic crisis (Centres for Disease Control, 2020). Stressing developed countries in general and developing states in particular, COVID-19 has the potential to generate negative social effects which will leave longstanding and deep scars (Adom, 2020; Fontanesi et al., 2020; Schuengel, Tummers, Embregts \& Leusink, 2020).

Closing down of schools and day care centres due to COVID-19 lockdown has put extra pressure on the parents to teach their children at home in addition to managing the caregiving duties, family activities, and work needs (Neece et al., 2020; Özdemir \& Kerse, 2020; Redquest, Tint, Ries \& Lunsky, 2021). According to Fontanesi et al. (2020), working parents have reported implausible strain on their resources, time, and efficiency to manage the everyday needs of home schooling and parenting. Moreover, researchers have documented the negative effect of COVID-19 lockdown on mental health (Almeida, 2020; Mazza et al., 2020; Zaagsma et al., 2020). According to a recent survey, the psychological effects of COVID-19 lockdown upon families, mainly include financial stress, boredom, stigma, confusion, frustration, anger, and post-traumatic stress symptoms (Brooks et al., 2020; Pulido Rodríguez, Villarejo Carballido, RedondoSama, Guo, Ramis \& Flecha, 2020).

Youth, particularly children, are also the victims of these psychological effects (Redquest, Tint, Ries \& Lunsky, 2020). This is evidenced by the negative impact of COVID-19 lockdown on youth (aged between 3 to 18 years) reported in a study conducted in Italian and Spanish families (Orgiles et al., 2020). In a sample of 1143 families, 85.7 percent reported that due to shutdown of schools, the child's social interaction has been restrained and their emotional state has altered. Children are becoming subject to irritability, 
boredom, impatience, learning difficulty, and nervousness. Besides, these increasing emotional symptoms of children exacerbate the parenting stress (Orgiles et al., 2020). These findings affirm the philosophy of interdependence in parent-child adjustment and transactional parent-child effects on substantial negative worldly activities for example, natural disasters (Juth et al., 2015; Özdemir \& Kerse, 2020).

In developing countries, particularly Pakistan, the negative impact of COVID-19 is still unfolding and less is known about it. Thus, limited knowledge is available to see the psychological effects on households having children with intellectual and developmental disabilities (IDDs). Existing literature in European context argued that the negative impact of COVID-19 is more on parents caring for children with IDDs in comparison to the general population (Nearchou, Flinn, Niland, Subramaniam \& Hennessy, 2020; Neece et al., 2020). For instance, a survey was conducted by Fontanesi et al. (2020) on a sample of 1126 families to understand the COVID-19 impact on families in Italy. The outcomes suggested that parents of children with physical or mental disabilities perceived less social support and signify a high degree of parental burnout in comparison to parents of children with no handicap. Moreover, parents of children with physical or mental disabilities have reported psychological changes in their child's behavior such as inability to concentrate, general discomfort, distractibility, and fussiness. Thus, Fontanesi et al.'s (2020) study concluded that COVID-19 pandemic has increased stress on parents of children with physical or mental impairments.

The associated disorders in routine and obvious implausibility due to COVID-19 pandemic may be adverse particularly for children with IDDs (Nearchou et al., 2020; Redquest et al., 2021). Before this pandemic, life for children with IDDs was with clear expectations, heightened structure, and an array of services (Ho, Perry \& Koudys, 2021; Mazza et al., 2020). However, the substantial changes in the routine during the pandemic may be difficult to absorb by these children, thus aggravating parents' stress levels (Brooks et al., 2020; Schuengel et al., 2020). Parents of children with IDDs are required to execute diverse functions for their children during this pandemic, mainly speech-language pathologist, social skills coach, special educator, and behavioral health therapist (Eshraghi et al., 2020; Jeste et al., 2020). This is because intensive support and services are needed for children with IDDs (McIntyre, 2020; Nearchou et al., 2020). The intensive support and services 
become the exclusive duty of the parents and it generally includes specialized coaching in the pattern of speech therapy, physical therapy, behavioral programing, special training, and social skills tutoring (National Research Council, 2001). This eventually intensifies the degree of stress on parents (Neece et al., 2020; Zaagsma et al., 2020). Even in the absence of this pandemic, parents of children with IDDs struggle with the parenting stress (Almeida, 2020; Ho et al., 2021; Woodman, Mawdsley \& Hauser-Cram, 2015). Children's challenging behavior is another factor which heightens parenting stress (Baker, McIntyre, Blacher, Crnic, Edelbrock \& Low, 2003), which affects the parents' adjustment and vice versa (Shivers, 2019; Woodman et al., 2015).

Developing nations like Pakistan hold additional challenges for parents of children with IDDs due to their weak economic and legislative structure (Shafi, Liu \& Ren, 2020). According to World Health Organization (2020) estimates, 15 percent of Pakistan's children population consists of children with IDDs and the country struggles to mainstream the limited constitutional cover and sketchy definitions for children with IDDs. Parents of children with IDDs challenges escalates in Pakistan due to deficiency of government funding in terms of policy making (Shafi et al., 2020). Since 1960s, the regime in the country is unable to establish consensus over the internal definition of children with IDDs. And after 18th Amendment, the central governmental control for policy making in Pakistan has declined and provinces failed to draft the national definition of children with IDDs in accordance with the UN Convention on the Rights of People with Disability.

Therefore, considering these contextual risks that parents of children with IDDs are facing, particularly those families having financial constraints, and physical/mental health challenges of the COVID-19, the present study attempts to investigate the parents' perspectives of COVID-19's impact in a sample of families of children with IDDs living in the rural part of Pakistan.

\section{Method}

Pakistan has a population of 220 million. $70 \%$ of the country's population resides in the rural part of the country, which differs socio-cultural and economic from the urban part. The income level is generally low and the 
primary income earners are associated with the agricultural sector. In addition to the national language, people in rural areas prefer to speak their native language and practice a different culture from other villages. A sample of 176 parents of children (aged between 3 to 5 years) with IDDs from rural areas of two principal cities (Lahore and Karachi) of Pakistan participated in the present study. These two cities were selected since both (Lahore and Karachi) are the central capitals of highest population provinces (Punjab and Sindh respectively) in the country. Both of these provinces are technologically more advanced than other provinces and have a mixed cultural approach to the country. People are comparatively educated and understand the living standards of the country.

Maximum variation sampling technique was used to select the present study participants. In Pakistan, community health workers (CHWs) system exists. CHWs' primary role is to offer basic health care facilities as well as information to the families to meet with the daily health-related challenges, particularly to women in rural parts of the country. For this reason, CHWs were contacted to identify and approach the families with children with IDDs. The present study therefore used the stratified random sampling technique to identify such families and they are readily available for study participation (Neece et al., 2020). 235 parents of children with IDDs were approached in the rural parts of Lahore and Karachi. Ultimately, 176 parents agreed to participate in the research study. The decline rate was 25 percent. The major grounds of refusal were due to hesitation to participate in any research study, COVID-19 social distancing measures, time constraints, and frustration with government policies. The interview technique was used to collect the relevant information and open-ended interview questions were asked to gather maximum input.

Informed consent for voluntarily participation in the present research was also taken from the families. 176 families' interviews were conducted in their houses as per their convenience due to COVID-19 movement restriction. Each interview lasted from 30 to 40 minutes and they were audio recorded for further coding. The total duration for collection of information of the present research comprised of 6 months (July to December, 2020). The following modified questions were adopted from study of Neece et al. (2020) and questioned in native language (Urdu) to the parents of children with IDDs; 
1. Please explain your life experience and major difficulties during COVID19 lockdown in the country.

2. What effects COVID-19 has brought to your children with IDDs and their life?

3. Have you received any benefits or services for your children with IDDs during this pandemic?

4. What strategies have you adopted to cope with the COVID-19 challenges?

5. How do you see the long-term impacts of COVID-19 pandemic on your family life?

Considering the social norms and boundaries of the women in the rural parts of the country, one female interview assistant was recruited from the university in Lahore. After imparting necessary training to the interview assistant, the interviews were conducted with the parents of children with IDDs. After collection of necessary information from the interviews, the recorded interviews were transcribed through NVIVO-10 software for qualitative data analysis (Neece et al., 2020). All interviews were then analyzed carefully to generate nodes and coding of information into relevant nodes. This systematic review of interviews enabled generation of themes for summary (Berg, 2009; Corbin \& Strauss, 2008). In order to achieve greater accuracy in generating themes, the principal researcher and interview assistant independently coded the interview responses according to interview questions (Neece et al., 2020). The reliability among the two coders was then checked and to remove any disagreements in the ratings, the coders' discussion was carried out to reach consensus. Hence, the two independent coder reliability improved and correlation coefficients of 0.95 was reached. The discussion of the present research is based on the consensus codes and they are reported descriptively.

\section{Participants’ Demographics}

From the present study participants (176 parents), the majority were mothers of children with IDDs (77.27\%). Table 1 represents the complete demographics of the study participants. The majority of participant were married (90.91\%) with 2 or more children. The majority of children with IDDs 
88 Munir et al. - Young Children with IDDs during COVID

in the present study sample were male (68.18\%) and diagnosed with intellectual impairment.

Table 1.

Sociodemographic Characteristics of In-depth Interviews ( $N=22)$ Participants

Demographic Variable

Age

Less than 30 years

30 to 40 years

More than 40 years

n

$\%$

Gender

Mother/Female

16

9.09

Father/Male

136

77.27

$24 \quad 13.64$

Marital Status

Married

136

77.27

Single Parent

$40 \quad 22.73$

$160 \quad 90.91$

$16 \quad 9.09$

Family Monthly Income (PKR)*

Less than 20,000

72

40.91

20,000 to 40,000

36.36

More than 40,000

64

22.73

Education

No Schooling

40

(2).73

Up to 10 years of Schooling

$\begin{array}{ll}8 & 4.55\end{array}$

More than 10 years of Schooling

$56 \quad 31.82$

$112 \quad 63.64$

Source of Income

Private Sector Job

$\begin{array}{ll}88 & 50.00\end{array}$

Government Sector Job

Own Business

56

18.18

Number of Children

0 to 2 Children

32

18.18

3 to 4 Children

$\begin{array}{ll}8 & 4.55\end{array}$

$120 \quad 68.18$

More than 4 Children

$48 \quad 27.27$

\section{Child Characteristics}

Age

Less than 02 years

$16 \quad 9.09$

3 to 4 years

$144 \quad 81.82$

More than 4 years

$16 \quad 9.09$

Gender

Male

120

68.18

Female

56 31.82

* $01 \mathrm{USD}=165$ PKR 
Table 2.

Parents Challenges and difficulties during COVID-19 lockdown ( $n=176)$

\begin{tabular}{|c|c|c|c|}
\hline Type of Challenge & n & $\%$ & Illustrative Quote \\
\hline \multicolumn{4}{|l|}{ Financial Constraint } \\
\hline $\begin{array}{l}\text { Losing Job and Closing } \\
\text { Down of Businesses }\end{array}$ & 48 & 27.27 & $\begin{array}{l}\text { "The job helps to earn the basic necessities of life. } \\
\text { COVID-19 makes it difficult to keep up with your } \\
\text { monthly salary" }\end{array}$ \\
\hline $\begin{array}{l}\text { Expensive Medical } \\
\text { Facilities }\end{array}$ & 24 & 13.64 & $\begin{array}{l}\text { "Medication and other associated facilities were } \\
\text { employed to be approachable, but at present they } \\
\text { are really expensive to buy" }\end{array}$ \\
\hline $\begin{array}{l}\text { Accessibility to } \\
\text { Consumable Items }\end{array}$ & 16 & 9.09 & $\begin{array}{l}\text { "The lockdown has offered the shortage of } \\
\text { consumable items supply at the stores thus, } \\
\text { making them expensive for a home" }\end{array}$ \\
\hline $\begin{array}{l}\text { Inadequate Govt. } \\
\text { Funding }\end{array}$ & 8 & 4.55 & $\begin{array}{l}\text { "In the absence of Govt. level support, it has } \\
\text { become so hard to oversee the events relevant to } \\
\text { my child with IDDs" }\end{array}$ \\
\hline
\end{tabular}

Staying at Home

Balancing Work $\quad 8 \quad 4.55$

"My spouse use to work wholeheartedly for the family, but now my spouse stays more at home due to lockdown and feels demotivated"

"I use to wake up ahead of time in the morning and

Changes in Routine $\quad 8 \quad 4.55$ use to go for exercise, but the lockdown is changing my everyday procedure and increased my sleeping habits"

"It has become difficult to offer the good childcare

$\begin{array}{lll}\text { Childcare } & 16 \quad 9.09\end{array}$ at home rather we use to give them at day care or at hospitals"

"Due to closure of public places and parks, my kids

Boredom for Kids $\quad 8 \quad 4.55$ feels boredom at home. Kids use to play with other children at the parks, but now no such routine"

\section{Health Conditions}

Avoidance of COVID 19

\section{Disparity in Child's daily} routine

Child's Behavior $\quad 16 \quad 9.09$

"The major challenge which I see is to keep the health conditions upright and to avoid the COVID19 in our home as it has no cure"

"At that place is a substantial impact of COVID19 lockdown on the child's behavior because they feel frightened and irritated while staying at home" 


\section{Results}

\section{Major Difficulties during COVID-19 Lockdown}

Parents were asked to identify the most difficult aspects of COVID-19 lockdown. Table 2 provides the difficult things identified by the parents during interviews. The most frequent issue identified was the financial constraint during the pandemic. Among those parents who identified the financial constraint, the bulk (27.27\%) said that losing their job and closing down of businesses were most challenging in order to satisfy the basic demands of households, followed by the need for expensive medical facilities (13.64\%) due to limited medical workforce in hospitals. Other challenges relevant to financial constraints identified include accessibility to consumable items $(9.09 \%)$ and inadequate government funding (4.20\%). Parents of children with IDDs also reported that staying at home has created challenges relevant to balancing work, changes in routine, childcare, and boredom for their children. All this new challenging routine generated the stoppage of development services for children with IDDs and scarcity of progressive educational demands. Moreover, a few parents (13.64\%) emphasized the health conditions and avoidance of COVID-19 for their children with IDDs as of central importance. Lastly, a subset of parents (9.09\%) stated that COVID19 has offered the substantial changes in the child's behavior due to a disparity in the child daily routine and inability to leave the house.

\section{COVID-19 Effects on Children with IDDs and their Life}

The parents in the rural parts of the two cities (Lahore and Karachi) reported that children with IDDs are suffering the most. The behavior of the children has changed due to spending the majority of their time at home. The children with IDDs use to visit coaching and educational centres where they had the opportunity to interact with other children. However, COVID-19 restrictions have isolated these children in homes and their learning abilities have declined $(54.55 \%)$. Table 3 provides the percentage of feedback received from various parents regarding the effects of COVID-19 on children with IDDs. 
Table 3.

COVID-19 Effects on Children with IDDs and their Life $(n=176)$

\begin{tabular}{llll}
\hline Type of Challenge & $\mathbf{n}$ & $\%$ & Illustrative Quote \\
\hline
\end{tabular}

Educational Services

Reduction in

Learning Capabilities

$96 \quad 54.55$

Inadequate Health

Education and

Services

$40 \quad 22.73$

Decrease in Services

Limited Social

Interaction

$24 \quad 13.64$

Closure of Health

Facilities
$16 \quad 9.09$
"My child used to earn many new things at coaching school. However, COVID-19 has taken our hopes for his fast recovery"

"We receive limited and challenging health education for children with IDDs in the rural regions of the metropolis"

"My child is stuck at home. She has many friends at school. However, COVID-19 has restricted her social interaction with her friends and learning habits"

"The basic health facilities have stopped all operations and engaged in fighting against COVID-19 thus created a challenge for us"

\section{Perceived Benefits for Children with IDDs during COVID-19}

The parents reported that in rural parts of the country, the government support was available inadequately $(95.45 \%)$. Government owns a basic health facility network in the fringes of the rural areas where hospital services are not approachable. Still, these basic health facilities were lacking medical staff as well as resources to counter the pandemic. Even the new-born child vaccination was stopped, and parents had to rely on private hospitals, which were expensive to impose for a financially challenged family.

On the other hand, the time parents had with the children at home was beneficial in various ways during the pandemic as shown in Table 4. For example, half of the parents reported that they had more chance to interact with their children with IDDs and teach them the basic cultural values of their respective communities $(50.00 \%)$. Other parents had the opportunity to teach the basic native language skills (31.82\%). Moreover, a subset of parents also reported that the children with IDDs have showed development gains because of increased interaction with all household members (18.18\%). 
Table 4.

Perceived Benefits for Children with IDDs during COVID-19

\begin{tabular}{|c|c|c|c|}
\hline Type of Benefit & n & $\%$ & Illustrative Quote \\
\hline \multicolumn{4}{|l|}{$\begin{array}{l}\text { Governmental } \\
\text { Support }\end{array}$} \\
\hline $\begin{array}{l}\text { Adequate } \\
\text { government } \\
\text { health facility }\end{array}$ & 8 & 4.55 & $\begin{array}{l}\text { "We experience a basic health facility center in our } \\
\text { area and lady health worker occasionally visits our } \\
\text { place for our child care instructions" }\end{array}$ \\
\hline $\begin{array}{l}\text { Inadequate } \\
\text { government } \\
\text { health facility }\end{array}$ & 168 & 95.45 & $\begin{array}{l}\text { "COVID-19 has restricted the movement of the } \\
\text { people in the community and therefore, the } \\
\text { government temporarily converted all basic health } \\
\text { facilities into quarantine centers" }\end{array}$ \\
\hline \multicolumn{4}{|l|}{ Other Benefits } \\
\hline $\begin{array}{l}\text { Increased } \\
\text { interaction and } \\
\text { inculcating basic } \\
\text { cultural values }\end{array}$ & 88 & 50.00 & $\begin{array}{l}\text { "I was mostly in office during the daytime, but now } \\
\text { I get the opportunity to play with my child with } \\
\text { IDDs and teach her the basic cultural values of our } \\
\text { society" }\end{array}$ \\
\hline $\begin{array}{l}\text { Teaching } \\
\text { language skills }\end{array}$ & 56 & 31.82 & $\begin{array}{l}\text { "Children learn fast in the growing years. I am } \\
\text { practicing and speaking my native language mostly } \\
\text { so that my child could also learn it" }\end{array}$ \\
\hline $\begin{array}{l}\text { Development } \\
\text { gains }\end{array}$ & 32 & 18.18 & $\begin{array}{l}\text { "Although I have perceived major challenges for } \\
\text { my child with IDDs during this lockdown, still due } \\
\text { to majority of time at home my child is responding } \\
\text { well which is a good news for me" }\end{array}$ \\
\hline
\end{tabular}

\section{Coping Strategies}

Parents of the children with IDDs were also asked about coping skills parents have adopted during this challenging time of COVID-19. Table 5 describes the response percentages with reference to each coping strategy. Although people residing in rural regions have limited knowledge regarding such coping strategies, parents were still able to develop few based on their experiences and cultural practices to productively engage their children with IDDs.

A range of coping strategies were identified during the in-depth interviews of the parents. The bulk of the respondents talked about the reinforcement system as a major tool as well as meshing with the family members in various enjoyable activities (e.g. playing outside, family games). Additionally, parents also identified eating healthy, exercising, meditation, getting in touch with 
other family relatives, and watching entertaining programs on television as helping to act as coping strategies for children with IDDs during pandemic.

A subset of parents $(18.18 \%)$ was not familiar with coping strategies because of limited access to the necessities of life such as basic education, awareness of social rights, medical facilities etc. These parents also identified challenges in terms of financial ability and awareness in order to care for their children with IDDs in rural Pakistan.

\section{Table 5.}

\section{Coping Strategies for Children with IDDs during COVID-19 $(n=176)$}

\begin{tabular}{|c|c|c|c|}
\hline Type of Benefit & $\mathbf{n}$ & $\%$ & Illustrative Quote \\
\hline Reinforcement System & 48 & 27.27 & $\begin{array}{l}\text { "My child was attending special school prior to the } \\
\text { COVID-19 containment. So I set up the same learning } \\
\text { schedule for him at home to give him the impression } \\
\text { that his routine has not changed." }\end{array}$ \\
\hline $\begin{array}{l}\text { Engaging in Enjoyable } \\
\text { Activities }\end{array}$ & 24 & 13.64 & $\begin{array}{l}\text { "Planning various gaming activities with friends and } \\
\text { family engages my child with IDDs and provides a } \\
\text { refreshing attitude in his personality" }\end{array}$ \\
\hline Eating Healthy & 24 & 13.64 & $\begin{array}{l}\text { "Good food and balanced nutrition is a fundamental } \\
\text { part of growing and grooming children. I am therefore } \\
\text { focusing on developing good eating habits for my } \\
\text { IDDs-affected child so that she can develop a good } \\
\text { mental health" }\end{array}$ \\
\hline Exercising & 16 & 9.09 & $\begin{array}{l}\text { "I take my child to our fields and we do various } \\
\text { exercises in the mud so that my child feels entertained } \\
\text { and can also be physically fit". }\end{array}$ \\
\hline Meditation & 8 & 4.55 & $\begin{array}{l}\text { "I speak to my child every day and every night about } \\
\text { the positive side of life, engaging his mind to reflect } \\
\text { on the optimistic side of life so he feels more } \\
\text { confident". }\end{array}$ \\
\hline $\begin{array}{l}\text { Getting in Touch with } \\
\text { Other Relatives }\end{array}$ & 8 & 4.55 & $\begin{array}{l}\text { "I take my child with IDDs to visit the related } \\
\text { neighbouring houses and we spend time so that his } \\
\text { environment changes and he should not feel like his } \\
\text { movement is limited to home only". }\end{array}$ \\
\hline $\begin{array}{l}\text { Watching Entertaining } \\
\text { Programs }\end{array}$ & 16 & 9.09 & $\begin{array}{l}\text { "I find quality time during this lockdown to see } \\
\text { various entertaining programs, particularly cartoons } \\
\text { with my child at home. Practicing this, he passes his } \\
\text { time with me equally comfortably as he sees his } \\
\text { favourite cartoons" }\end{array}$ \\
\hline
\end{tabular}


Table 6.

Long Term Impacts for Children with IDDs during COVID-19 $(n=176)$

\begin{tabular}{|c|c|c|c|}
\hline Type of Benefit & $\mathbf{n}$ & $\%$ & Illustrative Quote \\
\hline \multicolumn{4}{|l|}{$\begin{array}{l}\text { Changes in Emotional } \\
\text { Status }\end{array}$} \\
\hline $\begin{array}{l}\text { Engagement at } \\
\text { Schools and } \\
\text { Hospitals }\end{array}$ & 48 & 27.27 & $\begin{array}{l}\text { "My child was used to spending quality time } \\
\text { in school where his learning abilities were } \\
\text { increasing. However, his emotional condition } \\
\text { is changing because of his more time at home } \\
\text { now." }\end{array}$ \\
\hline $\begin{array}{l}\text { Practical and Social } \\
\text { Skills }\end{array}$ & 40 & 22.73 & $\begin{array}{l}\text { "As my child stays at home more often } \\
\text { because of a pandemic, his practical and social } \\
\text { skills are affected. It makes him feel alone and } \\
\text { sad". }\end{array}$ \\
\hline \multicolumn{4}{|l|}{ Behavioral Status } \\
\hline $\begin{array}{l}\text { Feelings of } \\
\text { Happiness and } \\
\text { Sadness }\end{array}$ & 24 & 13.64 & $\begin{array}{l}\text { "Since the lockdown has started, my child's } \\
\text { behavioral conditions have shifted } \\
\text { significantly. She is more sad and irritated". } \\
\text { "My child's mental growth has been affected } \\
\text { by a lack of education. He has become lazy } \\
\text { and now his interests in learning new words } \\
\text { have fallen" }\end{array}$ \\
\hline \multicolumn{4}{|l|}{$\begin{array}{l}\text { Other Long Term } \\
\text { Impacts }\end{array}$} \\
\hline Social Changes & 24 & 13.64 & $\begin{array}{l}\text { "As a result of the change in routine of all the } \\
\text { surrounding activities, my child began to feel } \\
\text { that he is in a different state of time where } \\
\text { most of the people around him are ill. He } \\
\text { understands the fear of the COVID-19 virus." } \\
\text { "The COVID-19 pandemic is a temporary } \\
\text { illness that does not impact the life of my child } \\
\text { with IDDs." }\end{array}$ \\
\hline
\end{tabular}

\section{Long-Term Impact}

During the interviews, parents were also asked how they perceived the longterm impact of COVID-19 on the lives of children with IDDs. Table 6 describes the response percentages of the long-term effect of COVID-19. Few parents $(13.64 \%)$ reported that the pandemic would have no impact on children with IDDs.

Most parents described changes in the emotional status of children with IDDs due to pandemic lockdown. Children were engaged in various activities in schools and hospitals for grooming (27.27\%) and to address challenges 
related to physical and mental impairment. However, pandemic lockdown resulted in children staying at home, which affected their understanding of practical and social skills $(22.73 \%)$. In addition, parents have also identified the behavioral status of children with IDDs as a major concern. Behavioural status is usually derived from a child's feelings of happiness and sadness (13.64\%). Children with IDDs respond positively if they are happy and excited with their new routine, particularly, staying at home and spending time with family members. In addition, few parents $(9.09 \%)$ reported that if lockdown continued longer (e.g. 6 months longer) the pandemic would have a wide range of negative impacts on children with IDDs. In particular, parents expressed that if special schools for children failed to resume, a lack of developmental and educational progress would have long-term impacts on children's mental growth.

The social changes (13.64\%) which include early closure of markets, shutting down all common play areas and parks, wearing of face masks, meeting each other with social distancing, and not shaking hands are likewise the key drivers for the long term impact of pandemic on children with IDDs.

\section{Discussion}

This study sample identified a variety of concerns related to lockdown as part of the COVID-19 pandemic and their effect on the lives of children with IDDs in rural Pakistan. Precisely, staying in the home affects the children's behavior, social and emotional status, environmental and cultural changes, and the growth of intellectual development. In addition, parents were also affected by lockdown related to COVID-19. Parents are facing financial challenges, stress issues, child grooming burden, limited health facilities for children, and inadequate government funding. To cope with these challenges, parents are able to develop few in house plans for the children. For instance, healthy food, exercising, engaging in enjoyable activities, gaming, and meeting with relatives. On the other hand, a few parents also expressed the benefits of COVID-19 lockdown by spending more time with their children, which reinforces their family ties.

The findings of this study are aligned with the recent reports on the impact of COVID-19 on families. For example, the burden of the COVID-19 


\section{Munir et al. - Young Children with IDDs during COVID}

pandemic is greater for parents with IDDs-challenged children than the parents of non-IDD-challenged children (Coyne et al., 2020; Masters et al., 2020). The reason for this is that parents of children with IDDs are more susceptible to social and educational vulnerabilities (Adom, 2020; Fontanesi et al., 2020; Jeste et al., 2020). Particularly, in developing countries like Pakistan, rural regions have comparatively more socioeconomic, linguistic, and ethnic issues than urban parts of the country (Shafi et al., 2020). As a result, raising children with IDDs is a difficult job in rural Pakistan. According to Hayes and Watson (2013), increased challenges, which primarily include increased caregiving burden and parenting stress, are identified among parents of children with IDDs compared to families with typical developing children. As a result, this transactional relationship between the child's challenging behaviour and parental stress increases parents' difficulties during the COVID-19 pandemic and their ability to cope (Fontanesi et al., 2020; Woodman et al., 2015). Consequently, this translates into an overall reduction in services for children with IDDs in rural Pakistan and likely detrimental short and long-term effects on child development (Reichow \& Wolery, 2009). The report by the National Institute of Child Health and Human Development (2017) states that;

The early years are a critical window of intervention because of the plasticity of the brain and the possibility of rapid development gains.

Participants in this study were socio-economically, linguistically and ethnically diverse because rural practices are different from urban culture in Pakistan and the rural population speaks their local 'Punjabi' language (Shafi et al., 2020). This diverse participant's background is unusual for urban and modernized families with IDDs (Safer-Lichtenstein et al., 2019). Based on the existing literature review, the value of modernized families (e.g., familismo) is generally associated with human adaptation and improved well-being, especially in difficult environments (Ayón et al., 2010). Improved well-being for modernized families allows them to better adapt (Perez \& Cruess, 2014). As a result, the better adaption is helping these families improve their family relationships and spend quality time with other family members, which translates into unintended benefits from the pandemic. However, the rural families are unaware of their basic civil rights and their limited knowledge 
hinders them to overcome the stressful situation through mobilizing available resources. Hence, rural families struggle for improved well-being and to attain solutions for their problems.

According to Hooper et al. (2020), in developed countries like the US, resilient perspectives have identified different characteristics of families during COVID-19 based on their socioeconomic and health disparities. These disparities significantly affect individuals from cultural minority and racial backgrounds during the pandemic in the USA. Therefore, the results of the present study can be generalized and tested to other similar population where socio-economic and health conditions can have a considerable impact (positive/negative) on families due to strong familial linkages. Hence, the present study represents a snapshot of the difficulties experienced by parents of children with IDDs in rural Pakistan in the year 2020. However, the longterm impacts of the pandemic are yet to be fully studied by academicians and researchers.

Healthcare workers or community workers in rural Pakistan are currently the only source for remote health service platforms and in their absence, medical assistance is scarce for children with IDDs. More research is needed to highlight the short and long-term impacts of COVID-19 lockdown on children with IDDs. This research has attempted to identify the perceived concerns of parents of children with IDDs during the pandemic and their views on how it affects their children. The study could serve as a baseline for future researchers and academics to further investigate what the Pakistan government is doing to eliminate these pandemic problems for children with IDDs. This study has highlighted the concerns of parents for their children with IDDs during the pandemic about closing schools and health institutions using qualitative data collection technique. All these identified challenges associated with being at home, providing full-time care to children, and implementing home learning mechanisms for children with IDDs could further be tested quantitatively in urban settings.

\section{Recommendations}

The present study has attempted to highlight the concerns of families with children with IDDs during the COVID-19 pandemic. It is recommended that 
health care professionals and other government agencies should actively support these families in rural regions of Pakistan. The support will be in the form of guidance, counselling, and offering opportunities for parents as well as children with IDDs to improve their social environment to appropriately overcome their issues during this distress time of COVID-19 lockdown. While social distancing and self-quarantine are effective means of preventing the spread of a pandemic, they may have a negative impact on people's wellbeing. Therefore, media through informative programs and public organizations through CHWs may offer procedures to adopt for improvement of physical health of children with IDDs which may eventually improve the children immunity as well as their leaning abilities. In fact, stable health conditions are key to fighting this pandemic and reducing parents' mental stress. For this reason, government and health professionals' focus should be on the well-being of parents and their children with IDDs and it should be a continuous process because this pandemic could have long lasting implications. According to Bowlby (1988):

\begin{abstract}
Man and woman power devoted to the production of material goods counts a plus in all our economic indices. Man and woman power devoted to the production of happy, healthy, and selfreliant children in their own homes does not count at all. We have created a topsy-turvy world (Bowlby, 1988).
\end{abstract}

\title{
References
}

Adom, D. (2020). Cultural and Educational Implications of the COVID-19 Global Pandemic in Ghana. International and Multidisciplinary Journal of Social Sciences, 9(3), 202-229. http://doi.org/10.17583/rimcis.2020.5416

Almeida, F. (2020). The Concept Of Human2Human In The Response To COVID-19. International and Multidisciplinary Journal of Social Sciences, 9(2), 129-151. http://dx.doi.org/10.17583/rimcis.2020.5524 Ayón, C., Marsiglia, F. F., \& Bermudez-Parsai, M. (2010). Latino family mental health: exploring the role of discrimination and familismo. Journal of Community Psychology, 38, 742-756. https://doi.org/10.1002/jcop.20392 
Baker, B. L., McIntyre, L. L., Blacher, J., Crnic, K., Edelbrock, C., \& Low, C. (2003). Preschool children with and without developmental delay: behavioral problems and parenting stress over time. Journal of Intellectual Disability Research, 47, 217-

230. https://doi.org/10.1046/j.1365-2788.2003.00484.x

Berg, B. L. (2009). Qualitative research methods for the social sciences. Allyn and Bacon.

Bowlby, J. (1988). A Secure Base: Parent-Child Attachment and Healty Human Development. London: Routledge.

Brooks, S., Webster, R. K., Smith, L. E., Woodland, L., Wessely,

S., Greenberg, N., \& Rubin, G. J. (2020). The psychological impact of quarantine and how to reduce it: rapid review of the evidence. Lancet, 395, 912-920. https://doi.org/10.1016/ S01406736(20)30460-8

Centers for Disease Control (2020). Cases in the U.S. Centers for Disease Control website https://www.cdc.gov/coronavirus/2019-ncov/casesupdates/cases-in-us.html

Corbin, J. M., \& Strauss, A. L. (2008). Basics of qualitative research: techniques and procedures for developing grounded theory. Sage Publications, Inc., Los Angeles. https://dx.doi.org/10.4135/9781452230153

Coyne, L. W., Gould, E. R., Grimaldi, M., Wilson, K. G., Baffuto, G., $\&$ Biglan A. (2020). First things first: Parent psychological flexibility and self-compassion during COVID-19. Behavior Analysis in Practice. https://doi.org/10.1007/s40617-020-00435-w

Eshraghi, A. A., Li, C., Alessandri, M., Messinger, D. S., Eshraghi, R. S., Mittal, R., \& Armstrong, F. D. (2020). COVID-19: overcoming the challenges faced by individuals with autism and their families. The Lancet. Psychiatry, 7(20), 481-483. https://doi.org/10.1016/S22150366(20)30197-8

Fontanesi, L., Marchetti, D., Mazza, C., Di Giandomenico, S., Roma, P. \& Verrocchio, M. C. (2020). The effect of the COVID-19 lockdown on parents: a call to adopt urgent measures. Psychological Trauma: Theory, Research, Practice, and Policy, 12, S79-S81. http://dx.doi.org/10.1037/tra0000672

Hayes, S. A., \& Watson, S. L. (2013). The impact of parenting stress: a meta-analysis of studies comparing the experience of parenting stress in parents of children with and without autism spectrum 
disorder. Journal of Autism and Developmental Disorders, 43, 629642. https://doi.org/10.1007/s10803-012-1604-y

Ho, H., Perry, A., \& Koudys, J. (2021). A systematic review of behaviour analytic interventions for young children with intellectual disabilities. Journal of Intellectual Disability Research, 65(1), 11-31.

https://doi.org/10.1111/jir.12780

Hooper, W., M., Nápoles, A. M., \& Pérez-Stable, E. J. (2020). COVID-19 and racial/ethnic disparities. JAMA, 323, 2466-2467.

https://doi.org/10.1001/jama.2020.8598

Jeste, S., Hyde, C., Distefano, C., Halladay, A., Ray, S., Porath, M., Wilson,

R. B., \& Thurm, A. (2020). Changes in access to educational and healthcare services for individuals with intellectual and developmental disabilities during COVID-19 restrictions. Journal of Intellectual Disability Research, 64(I2), 825-833.

https://doi.org/10.1111/jir.12776

Juth, V., Silver, R. C., Seyle, D. C., Widyatmoko, C. S., \& Tan, E.

T. (2015). Post-disaster mental health among parent-child dyads after a major earthquake in Indonesia. Journal of Abnormal Child

Psychology, 43, 1309-1318. https://doi.org/10.1007/s10802-015-00098

Masters, G. N., Taylor-Guy, P., Fraillon, J., \& Chase, A. (2020). Ministerial Briefing Paper on Evidence of the Likely Impact on Educational

Outcomes of Vulnerable Children Learning at Home during COVID19. Australian Government Department of Education, Skills and Employment.

Mazza, C., Ricci, E., Biondi, S., Colasanti, M., Ferracuti, S., \& Napoli, C. et al. (2020). Nationwide survey of psychological distress among Italian people during the COVID-19 pandemic: immediate psychological responses and associated factors. International Journal of Environmental Research and Public Health, 17, 1-14. https://doi.org/10.3390/ijerph17093165

McIntyre, L. L. (2020). Family-Based Practices to Promote Well-Being. American Journal on Intellectual and Development Disabilities, 125(5), 349-352. https://doi.org/10.1352/1944-7558-125.5.349

National Institute of Child Health and Human Development (2017). Early intervention and autism. National Institute of Child Health and Human Development

National Research Council (2001). Educating Children with Autism. The National Academies Press. 
Nearchou, F., Flinn, C., Niland, R., Subramaniam, S.S., \& Hennessy, E.

(2020). Exploring the Impact of COVID-19 on Mental Health Outcomes in Children and Adolescents: A Systematic Review.

International Journal of Environmental Research and Public

Health, 17(22), 79-84. https://doi.org/10.3390/ijerph17228479

Neece, C., Mclntyre, L.L., \& Fenning, R. (2020). Examining the impact of

COVID-19 in ethnically diverse families with young children with intellectual and developmental disabilities. Journal of Intellectual

Disability research, 64(10), 739-749. https://doi.org/10.1111/jir.12769

Orgilés, M., Morales, A., Delveccio, E., Mazzeschi, C., \& Espada, J.

P. (2020). Immediate psychological effects of COVID-19 quarantine

in youth from Italy and Spain. Frontiers in Psychology, 11, 2986.

https://doi.org/10.3389/fpsyg.2020.579038

Özdemir, S., \& Kerse, G. (2020). The Effects of COVID 19 Process on

Health Care Workers: Analysing of the Relationships between

Optimism, Job Stress and Emotional Exhaustion. International and

Multidisciplinary Journal of Social Sciences, 9(2), 178-201.

http://dx.doi.org/10.17583/rimcis.2020.5849

Perez, G. K., \& Cruess, D. (2014). The impact of familism on physical and mental health among Hispanics in the United States. Health

Psychology Review, 8, 95-127.

https://doi.org/10.1080/17437199.2011.569936

Pulido Rodríguez, C., Villarejo Carballido, B., RedondoSama, G., Guo, M.,

Ramis, M., \& Flecha, R. (2020). False News Around COVID-19

Circulated Less On Sina Weibo Than On Twitter. How To Overcome

False Information? International and Multidisciplinary Journal of

Social Sciences, 9(2), 107-128.

http://dx.doi.org/10.17583/rimcis.2020.5386

Redquest, B. K., Tint, A., Ries, H., \& Lunsky, Y. (2021). Exploring the experiences of siblings of adults with intellectual/developmental disabilities during the COVID-19 pandemic. Journal of Intellectual Disability Research, 65(1), 1-10. https://doi.org/10.1111/jir.12793

Redquest, B.K., Tint, A., Ries, H., \& Lunsky, Y. (2020). Exploring the experiences of siblings of adults with intellectual/developmental disabilities during the COVID-19 pandemic. Journal of Intellectual Disability Research, 65(1), 1-10. https://doi.org/10.1111/jir.12793

Reichow, B., \& Wolery, M. (2009). Comprehensive synthesis of early intensive behavioral interventions for young children with autism 
based on the UCLA young autism project model. Journal of Autism and Developmental Disorders, 39, 23-41. https://doi.org/10.1007/s10803-008-0596-0

Roesch, E., Amin, A., Gupta, J., \& Moreno, C.J. (2020). Violence against women during covid-19 pandemic restrictions. BMJ, 369. https://doi.org/10.1136/bmj.m1712

Safer-Lichtenstein, J., Hamilton, J., \& McIntyre, L. L. (2019). Examining demographics in randomized control trials of group social skills interventions for individuals with autism spectrum disorder. Journal of Autism and Developmental Disorders, 49, 3453-3461.

https://doi.org/10.1007/s10803-019-04063-4

Schuengel, C., Tummers, J., Embregts, P. J. C. M., \& Leusink, G. L. (2020). Impact of the initial response to COVID-19 on long-term care for people with intellectual disability: an interrupted time series analysis of incident reports. Journal of Intellectual Disability Research, 64(II), 817-824. https://doi.org/10.1111/jir.12778

Shafi, M., Liu, J., \& Ren, W. (2020). Impact of COVID-19 pandemic on micro, small, and medium-sized Enterprises operating in Pakistan. Research in Globalization, 2, 100018. https://doi.org/10.1016/j.resglo.2020.100018

Shivers, C. M. (2019). Self-Reported Guilt Among Adult Siblings of People With Intellectual and Developmental Disabilities. American Journal on Intellectual and Development Disabilities, 124(5), 470-477. https://doi.org/10.1352/1944-7558-124.5.470

Woodman, A. C., Mawdsley, H. P., \& Hauser-Cram, P. (2015). Parenting stress and child behavior problems within families of children with developmental disabilities: transactional relations across

15 years. Research in Developmental Disabilities, 36, 264-276. https://doi.org/10.1016/j.ridd.2014.10.011

World Health Organization (2020). Coronavirus disease (COVID-19) pandemic. World Health Organization website https://www.who.int/emergencies/diseases/novel-coronavirus-2019 Zaagsma, M., Volkers, K. M., Swart, E. A. K., Schippers, A. P., \& Hove, G. V. (2020). The use of online support by people with intellectual disabilities living independently during COVID-19. Journal of Intellectual Disability Research, 64(10), 750-756. https://doi.org/10.1111/jir.12770 
International and Multidisciplinary Journal of Social Sciences, 103

Malik Mamoon Munir is Assistant Professor at the Department of Management Sciences, at the Bahria Univesity of Islamabad, Pakistan. Dr. Mamoon has completed his PhD Degree in the field of Management Sciences from Bahria University Islamabad Pakistan.

Ume Rubaca is PhD Scholar at the Department of Management Sciences, Comsats University of Islamabad, Pakistan

Malik Haroon Munir is Master of Public Policy Scholar at the Crawford School of Public Policy, Australian National University, Australia

Bakhtawar Munir is MS Scholar at the Department of Humanities, Comsats University of Islamabad, Pakistan

Email: malikmamoonmunir@gmail.com 